\title{
Social rituals and onset of mental disorders
}

\author{
Aleksandar Janca \\ From $1^{\text {st }}$ International Congress on Neurobiology and Clinical Psychopharmacology and European \\ Psychiatric Association Conference on Treatment Guidance \\ Thessaloniki, Greece. 19-22 November 2009
}

The concept of a prodrome, or the very earliest signs of the onset of a mental disorder, is well known in clinical psychiatry, and refers to disturbances of ordinary behaviour that may precede the behaviour and experiences that constitute recognised psychiatric symptoms and signs. In the literature, however, prodromes are described simply by means of lists of behaviours, such as avoidance of meeting other people, irritability, polite greetings absent or minimal, poor table manners, conversation avoided or kept to a minimum, and lowering of standards of personal appearance and hygiene.

To examine a relationship between social rituals and onset of mental disorders, we decided to develop an instrument to measure changes in ritualistic behaviour during the prediagnostic stages of mental illness, and explore whether it could be used as a tool for early detection of individuals who are in, or at risk of soon developing poor mental health. The result is the Social Ritual Interview which consists of ten distinct domains which are based upon universal social rituals identified via extensive cross-cultural investigation.

Once the draft instrument was finalised, mental health professionals administered it upon 30 patients with a variety of mental disorders. The interview was then conducted with a close relative or other carer nominated by the patient, and the questions were asked in relation to the patient's appearance and behaviour. Data analysis found moderate to severe changes in most of the ten social ritual domains, meaning there is often an observable disrespect of such rituals during the prediagnostic stages of mental illness.

Published: 22 April 2010

School of Psychiatry and Clinical Neurosciences, University of Western Australia, Perth, Australia
References

1. Janca A, Cooper JE: Measurement of some novel concepts in psychiatry. World Psychiatry 2002, 1(2):107-108.

2. Janca A, Isaac M: Psychiatric assessment instruments: a review of recent developments. Advances in Psychiatry Athens: Beta Medical PublishersChristodoulou GN 2002, 99-106.

doi:10.1186/1744-859X-9-S1-S58

Cite this article as: Janca: Social rituals and onset of mental disorders. Annals of General Psychiatry 2010 9(Suppl 1):S58.
Submit your next manuscript to BioMed Central and take full advantage of:

- Convenient online submission

- Thorough peer review

- No space constraints or color figure charges

- Immediate publication on acceptance

- Inclusion in PubMed, CAS, Scopus and Google Scholar

- Research which is freely available for redistribution

Submit your manuscript at www.biomedcentral.com/submit
C Biomed Central 